\title{
Potensi Hasil Jagung Manis (Zea Mays Saccharata Sturt.) Hibrida Varietas Bonanza F1 Pada Jarak Tanam Berbeda
}

\author{
Trimin Kartika \\ e-mail: triminkartika1969@gmail.com \\ Program Studi Biologi Fakultas MIPA, Universitas PGRI Palembang
}

\begin{abstract}
The study entitled: Potential of Sweet Corn (Zea Mays Saccharata Sturt.) Hybrid F1 Bonanza Varieties at Different Planting Spaces. Aim to get the potential results of sweet corn (Zea Mays Saccharata Sturt.) Hybrid variety of Bonanza F1 with optimal spacing (Maximum production). The study was conducted in December 2018 until April 2019, at the Plantation Site of Tanjung Baru Petai Village, Tanjung Batu District, Ogan Ilir District (OI), South Sumatra Province. The experimental design used was Completely Randomized Design (CRD), 6 settings in 3 times required 6 x 3 $=18$ experimental units. The area of land used is 0.5 ha with spacing of $\mathrm{P} 1: 80 \mathrm{~cm} \mathrm{x}$ $25 \mathrm{~cm} 1$ seed / hole, P2: $75 \mathrm{~cm} \times 25 \mathrm{~cm} 1$ seed/ hole, P3: $80 \mathrm{~cm} \mathrm{x} 40 \mathrm{~cm} 2$ seeds / hole, P4: $60 \mathrm{~cm}$ x $25 \mathrm{~cm} 1$ seed / hole, P5: $75 \mathrm{~cm} \mathrm{x} 40 \mathrm{~cm} 2$ seeds / hole, P6: $75 \mathrm{~cm} \mathrm{x}$ $50 \mathrm{~cm} 3$ seeds / hole. The variables discussing sweet corn plants include tall plants $(\mathrm{cm})$, stem diameter $(\mathrm{mm})$, wide leaves $(\mathrm{cm} 2)$, leaf length $(\mathrm{cm})$, weighted fresh berangkasan (gr), ear length $(\mathrm{cm})$, ear diameter $(\mathrm{cm}))$, number of rows / ear, number of seeds / cob (seeds), weight of ear cob (gr), weight of ear without clobot (gr). The results showed that Bonanza F1 corn varieties proved very significant in plant height, stem diameter, ear length and number of rows per ear, significantly different in leaf width, leaf length, ear diameter, number of seeds per ear, and not significantly different from fresh weight berangkasan, heavy cob berklobot, the weight of the cob without a screw. P1 treatment with a spacing of $80 \mathrm{~cm} \times 25 \mathrm{~cm}$ (1 seed / hole) provides the best potential and has the potential to increase growth, yield and components of Bonanza F1.
\end{abstract}

Keywords: Varieties, Bonanza F1 Hybrid Corn, spacing, growth, yield

\begin{abstract}
ABSTRAK
Penelitian yang berjudul : Potensi Hasil Jagung Manis (Zea Mays Saccharata Sturt.) Hibrida Varietas Bonanza F1 Pada Jarak Tanam Berbeda. Bertujuan untuk mendapatkan potensi hasil jagung manis (Zea Mays Saccharata Sturt.) Hibrida varietas Bonanza F1 dengan jarak tanam yang optimal (Produksi yang maksimal). Penelitian dilaksanakan pada Desember 2018 sampai April 2019, bertempat di Lahan Perkebunan Desa Tanjung Baru Petai Kecamatan Tanjung Batu, Kabupaten Ogan Ilir (OI) Provinsi Sumatera Selatan. Rancangan percobaan yang digunakan adalah Rancangan Acak Lengkap (RAL), 6 perlakuan diulang 3 kali sehingga terdapat $6 \times 3$ $=18$ satuan percobaan. Luas lahan yang digunakan 0,5 ha dengan jarak tanam P1: 80 $\mathrm{cm} \times 25 \mathrm{~cm}$ 1biji /lubang, P2: $75 \mathrm{~cm}$ x $25 \mathrm{~cm}$ 1biji/lubang, P3: $80 \mathrm{~cm}$ x $40 \mathrm{~cm}$ 2biji/perlubang, P4: $60 \mathrm{~cm}$ x $25 \mathrm{~cm} 1$ biji/lubang, P5: $75 \mathrm{~cm} \mathrm{x} 40 \mathrm{~cm} 2$ biji/lubang, P6: $75 \mathrm{~cm} \times 50 \mathrm{~cm} 3$ biji/lubang. Peubah yang diamati pada tanaman jagung manis meliputi tinggi tanaman $(\mathrm{cm})$, diameter pangkal batang $(\mathrm{mm})$, luas daun $\left(\mathrm{cm}^{2}\right)$, panjang daun $(\mathrm{cm})$, berat segar berangkasan $(\mathrm{gr})$, panjang tongkol $(\mathrm{cm})$, diameter tongkol $(\mathrm{cm})$, jumlah baris/tongkol , Jumlah biji/tongkol (biji), berat tongkol berkelobot (gr), Berat tongkol tanpa klobot (gr). Hasil penelitian menunjukkan bahwa
\end{abstract}




\begin{abstract}
Varietas jagung Bonanza F1 berpengaruh sangat nyata pada tinggi tanaman, diameter pangkal batang, panjang tongkol dan jumlah baris per tongkol, berbeda nyata pada luas daun, panjang daun, diameter tongkol, jumlah biji per tongkol, dan tidak berbeda nyata pada berat segar berangkasan, berat tongkol berklobot, berat tongkol tanpa klobot. Perlakuan P1 dengan jarak tanam $80 \mathrm{~cm}$ x $25 \mathrm{~cm}$ (1 biji/lubang) memberikan pengaruh terbaik dan memiliki potensi meningkatkan pertumbuhan, hasil dan komponen hasil tanaman jagung manis Bonanza F1.
\end{abstract}

Kata Kunci: Varietas, Jagung Hibrida Bonanza F1, jarak tanam, Pertumbuhan, Hasil

\title{
PENDAHULUAN
}

Jagung manis merupakan komoditas yang memiliki nilai ekonomis yang tinggi, dan merupakan salah satu komoditas yang diminati oleh masyarakat Indonesia. Jagung manis sangat cocok tumbuh didataran Indonesia, karena syarat tumbuh jagung manis sesuai dengan karekteristik kondisi iklim dan tanah di wilayah Indonesia, jagung manis juga mempunyai nilai ekonomi yang tinggi sehingga dapat meningkatkan pendapatan petani. Permintaan jagung manis terus meningkat, bukan hanya untuk konsumsi rumah tangga melainkan juga untuk bahan baku industri (Iriany et al. 2011). Berdasarkan data Direktorat Jenderal Hortikultura (2012), volume impor jagung manis pada tahun 2012 adalah sebanyak 2674 ton, sedangkan volume ekspor pada tahun yang sama hanya mencapai 359 ton.

Peningkatan produksi dan produktivitas jagung selain melalui perluasan areal tanam, dapat dilakukan melalui ekstensifikasi, khususnya dari aspek teknologi budidaya, antara lain penggunaan varietas unggul dan pengaturan populasi tanaman. Penggunaan varietas saat ini lebih ditekankan pada pengembangan jagung hibrida karena memiliki banyak keunggulan dibandingkan dengan benih jagung biasa, keunggulan tersebut antara lain, masa panen lebih cepat, lebih tahan serangan hama dan penyakit serta produktifitasnya lebih tinggi.
Peningkatan produksi jagung ini dapat dilakukan dengan menyediakan kondisi yang sesuai untuk pertumbuhan dan perkembangan tanaman jagung yaitu dengan perbaikan teknik budidaya jagung, menggunakan bibit jagung varietas unggul, pemberian pupuk yang berimbang, pemberantasan hama dan penyakit dan proses pengolahan pasca panen yang baik dan benar (Novriani, 2010).

Dalam budidaya jagung manis, populasi tanaman perlu diperhatikan antara lain jumlah benih per satuan luasnya. Kerapatan tanaman sangat mempengaruhi hasil atau produksi tanaman. Hal ini terkait dengan tingkat kompetisi antar tanaman dalam memperoleh cahaya, air, ruang, serta unsur hara. Kerapatan tanaman dapat diatur dengan penggunaan jumlah benih yang tepat. (Arwani A et. Al. 2013). Penggunaan jumlah benih yang tepat akan memberikan hasil akhir yang baik, selain itu lebih efisien dalam penggunaan lahan (Harjadi, 2002).

Penanaman dengan jarak tanam bertujuan agar populasi tanaman mendapatkan bagian yang sama terhadap unsur hara yang diperlukan dan sinar matahari, dan memudahkan dalam pemeliharaan (Probowati 2014).

Di Indonesia ada berbagai macam jagung manis yang telah dibudidayakan yaitu, jagung manis varietas master manis, jagung manis varietas bicolour 
manis, jagung manis varietas bonanza, jagung manis varietas talenta, dan jagung manis varietas wanita manis . Dari sekian banyak jagung manis tersebut, varietas bonanza lah yang paling cocok untuk dibudidayakan. Varietas bonanza memiliki cita rasa yang sangat manis, dan daya simpannya cukup tinggi, dan memiliki hasil yang lebih baik dibandingkan dengan jagung manis. Jagung manis varietas bonanza yang sering dan sudah banyak dibudidayakan oleh masyarakat Indonesia adalah dari galur $f 1$. Jagung manis bonanza $f 1$ banyak dicari oleh petani jagung untuk dibudidayakan karena memiliki beberapa keunggulan, memiliki tongkol yang besar dengan biaya antara 300-480 gram / tongkol, potensi panen yang dapat mencapai 14-18 ton / ha, memiliki umur panen yang cukup singkat yaitu 70-85 HST (Hari Setelah Tanam).

Berdasarkan hasil penelitian Irvendi, 2016. bahwa penggunaan varietas Bonanza F1 memberikan hasil terbaik berpengaruh sangat nyata terhadap variabel tinggi tanaman, diameter batang, panjang tongkol, dan berat tongkol jagung manis dalam system tumpangsari dengan kacang tanah.

Tujuan dari penelitian ini Bertujuan untuk mendapatkan potensi hasil jagung manis (Zea Mays Saccharata Sturt.) Hibrida varietas Bonanza F1 dengan jarak tanam yang optimal (Produksi yang maksimal).

\section{BAHAN DAN METODE}

Penelitian ini telah dilakukan di Perkebunan Desa Tanjung Baru Petai Kecamatan Tanjung Batu Ogan Ilir. Pelaksanaan penelitian ini mulai bulan Desember 2018 sampai April 2019.

Alat yang digunakan yaitu cangkul, garu, gembor, tugal, papan nama, meteran, timbangan, kamera dan alat tulis.

Bahan yang digunakan dalam penelitian ini yaitu benih jagung manis varietas
Bonanza F1 yang di produksi oleh PT.East West Seed Indonesia, Jawa Barat, pupuk kandang sapi sebagai pupuk dasar, Urea, SP-36, dan KCl. Rancangan percobaan yang digunakan adalah Rancangan Acak Lengkap (RAL), 6 perlakuan diulang 3 kali sehingga terdapat $6 \times 3=18$ satuan percobaan. Luas lahan yang digunakan 0,5 ha dengan jarak tanam P1:80 $\mathrm{cm} \mathrm{x}$ $25 \mathrm{~cm}$ 1biji /lubang, P2: $75 \mathrm{~cm} \times 25 \mathrm{~cm}$ 1biji/lubang, P3: $80 \quad \mathrm{~cm} \quad \mathrm{x} \quad 40 \quad \mathrm{~cm}$ 2biji/perlubang, P4: $60 \mathrm{~cm} \times 25 \mathrm{~cm} 1$ biji/lubang, P5: $75 \mathrm{~cm} \quad \mathrm{x} \quad 40 \mathrm{~cm} \quad 2$ biji/lubang, P6: $75 \mathrm{~cm}$ x $50 \mathrm{~cm} 3$ biji/lubang. Peubah yang diamati pada tanaman jagung manis meliputi tinggi tanaman $(\mathrm{cm})$, diameter pangkal batang $(\mathrm{mm})$, luas daun $\left(\mathrm{cm}^{2}\right)$, panjang daun (cm), berat segar berangkasan (gr). panjang tongkol $(\mathrm{cm})$, diameter tongkol (cm), Jumlah baris/tongkol, Jumlah biji/tongkol (biji), berat tongkol berkelobot (gr), Berat tongkol tanpa klobot (gr).

\section{Analisis Data}

Data yang diamati dianalisis menggunakan analisis sidik ragam anova dengan Uji $\mathrm{F}$ taraf 5\%. Apabila hasil $\mathrm{F}$ hitung lebih besar dari $\mathrm{F}$ tabel pada taraf $(0,05),(0,1)$ perlakuan berbeda nyata maka dilanjutkan Uji BNT (Beda Nyata Trkecil) pada taraf $0,05 \%$.

\section{HASIL DAN PEMBAHASAN}

Dari hasil penelitian ini potensi hasil jagung manis Bonaza F1 dengan jarak tanam $80 \mathrm{~cm}$ x $25 \mathrm{~cm}$ merupakan jarak tanam terbaik. Diduga pada jarak tanam tersebut persaingan untuk mendapatkan unsur hara yang dibutuhkan oleh tanaman dalam jumlah yang lebih banyak dapat terbagi dengan merata sehingga kompetisi unsur hara antar tanaman tidak terjadi, .

Berdasarkan hasil dari analisis sidik ragam pada berbagai pengamatan menunjukkan perlakuan potensi tanaman 
jagung manis Bonanza F1 pada jarak tanam berbeda mengakibatkan perbedaan yang sangat nyata pada peubah yang diamati terhadap tinggi tanaman, diameter pangkal batang, panjang tongkol dan jumlah baris per tongkol, berbeda nyata pada luas daun, panjang daun, diameter tongkol, jumlah biji per tongkol, dan tidak berbeda nyata pada perubah berat berangkasan basah, berat tongkol berklobot, berat tongkol tanpa klobot.

Tabel 1. Hasil analisis keragaman pengaruh perlakuan terhadap peubah yang diamati.

\begin{tabular}{lllr}
\hline \multicolumn{1}{c}{ Peubah yang diamati } & \multicolumn{1}{c}{ F.Hitung } & \multicolumn{2}{c}{ F Tabel } \\
\cline { 3 - 4 } & & $\mathbf{0 , 0 5}$ & $\mathbf{0 , 0 1}$ \\
\hline Tinggi tanaman (cm) & $6,88^{* *}$ & 3,11 & 5,06 \\
Diameter pangkal batang (mm) & $10,1^{* *}$ & & \\
Luas Daun (cm2) & $3,75^{*}$ & & \\
Panjang Daun (cm) & $3,23^{*}$ & & \\
Berat berangkasan basah (gr) & $1,07^{\text {tn }}$ & & \\
Panjang Tongkol (cm) & $7,27^{* *}$ & & \\
Diameter Tongkol (cm) & $3,36^{*}$ & & \\
Jumlah baris/tongkol & $5,92^{* *}$ & & \\
Jumlah biji/tongkol (buah) & $3,52^{*}$ & & \\
Berat tongkol berklobot (gr) & $1,23^{\text {tn }}$ & & \\
Berat tongkol tanpa klobot (gr) & $2,31^{\text {tn }}$ & & \\
\hline
\end{tabular}

\section{Pertumbuhan}

\section{Tinggi Tanaman $(\mathbf{c m})$}

Berdasarkan hasil analisis ragam menunjukkan bahwa jarak tanam berpengaruh sangat nyata terhadap tinggi tanaman jagung manis Bonanza F1 pada umur 15 HST, $30 \mathrm{HST}$, dan 45 HST. Rata-rata tinggi tanaman umur 15 HST, 30 HST, dan 45 HST disajikan pada Tabel 2.

Tabel 2. Rata-Rata tinggi tanaman jagung manis umur 15 HST, 30 HST, dan 45 HST dengan jarak tanam berbeda.

\begin{tabular}{cllc}
\hline \multirow{2}{*}{ Perlakuan } & \multicolumn{2}{c}{ Tinggi Tanaman $(\mathbf{c m})$} \\
\cline { 2 - 4 } $\mathrm{P}_{1}$ & $\mathbf{1 5} \mathbf{H S T}$ & $\mathbf{3 0} \mathbf{H S T}$ & $\mathbf{4 5} \mathbf{H S T}$ \\
$\mathrm{P}_{2}$ & $29,47 \mathrm{a}$ & $95,96 \mathrm{a}$ & $175,70 \mathrm{a}$ \\
$\mathrm{P}_{3}$ & $28,93 \mathrm{a}$ & $91,10 \mathrm{a}$ & $169,21 \mathrm{a}$ \\
$\mathrm{P}_{4}$ & $27,43 \mathrm{ab}$ & $89,70 \mathrm{ab}$ & $155,19 \mathrm{ab}$ \\
$\mathrm{P}_{5}$ & $25,34 \mathrm{~b}$ & $87,10 \mathrm{ab}$ & $153,88 \mathrm{ab}$ \\
$\mathrm{P}_{6}$ & $25,47 \mathrm{~b}$ & $83,71 \mathrm{~b}$ & $150,19 \mathrm{~b}$ \\
\hline
\end{tabular}

Keterangan : Angka yang diikuti oleh huruf yang sama pada kolom yang sama tidak berbeda nyata pada taraf 5\% (Uji BNJ 0.05)

Tabel 2 menunjukkan bahwa potensi tanaman jagung manis Bonanza F1 berpengaruh sangat nyata terhadap pertumbuhan tinggi tanaman jagung manis pada umur 15 HST, 30 HST, dan
45 HST dengan jarak tanam berbeda. Pertumbuhan tinggi tanaman yang terbaik dijumpai pada perlakuan P1 disajikan pada Grafik 1. 


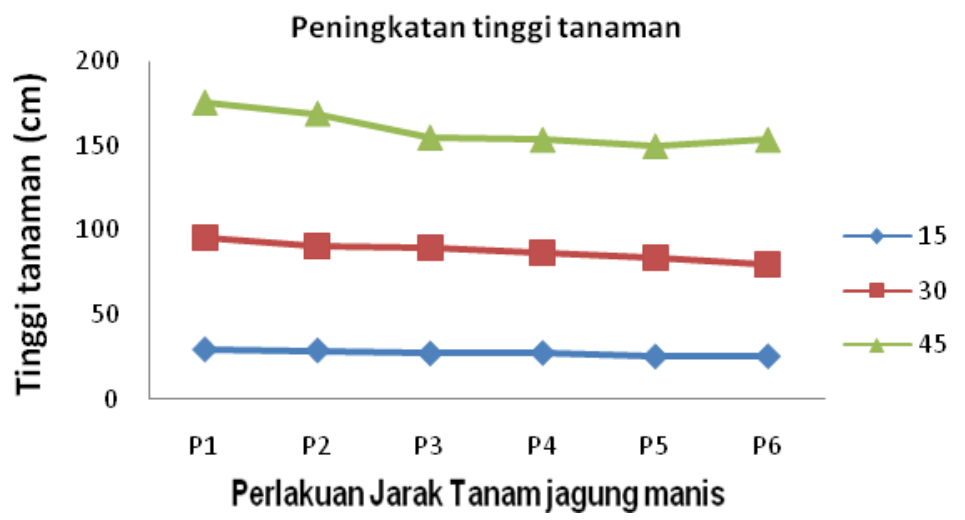

Grafik 1. Tinggi tanaman jagung manis umur 15 HST, 30 HST, dan 45 HST dengan jarak tanam berbeda.

Grafik 1. Menunjukkan bahwa perlakuan P1 dengan jarak tanam 80 $\mathrm{cm} \quad \mathrm{x} \quad 25 \mathrm{~cm}(1 \mathrm{biji} / \mathrm{lubang})$ dapat memberikan pertumbuhan tinggi tanaman jagung Bonanza F1 yang lebih baik di banding dengan perlakuan lainnya terjadi peningkatan dan terjadi penurunan terendah pada perlakuan P6 jarak tanam $75 \mathrm{~cm}$ x $50 \mathrm{~cm}$ (3 biji/lubang). Hal ini di sebabkan oleh perbedaan jarak tanam mempengaruhi tinggi tanaman, jarak tanam yang rapat terlihat kecenderungan bahwa semakin rapat jarak tanam terjadinya persaingan unsure hara, cahaya, air, dan ruang tunggu. Hal ini sesuai dengan pendapat Irvendi (2016) yang menyatakan bahwa proses pembentukan asimilat tanaman membutuhkan cahaya dan air yang cukup, kekurangan cahaya dan air dapat menyebabkan penurunan pembentukan asimilat sehingga pertumbuhan tanaman terhambat.

Hasil analisis sidik ragam menunjukkan bahwa potensi jagung manis Bonanza F1 dengan jarak tanam berbeda berpengaruh sangat nyata terhadap diameter pangkal batang berpengaruh nyata nyata terhadap luas daun, panjang daun, berbeda tidak nyata pada berat segar berangkasan yang diamati pada umur 45 HST. Rata-rata diameter pangkal batang, luas daun, panjang daun, dan berat segar berangkasan disajikan pada tabel 3 .

Tabel 3. Rata-Rata Diameter Pangkal Batang Jagung Manis Bonanza F1 dengan jarak tanam berbeda.

\begin{tabular}{ccccc}
\hline Perlakuan & $\begin{array}{c}\text { Diameter Pangkal } \\
\text { Batang }(\mathrm{cm})\end{array}$ & $\begin{array}{c}\text { Luas daun } \\
\left(\mathrm{cm}^{2}\right)\end{array}$ & $\begin{array}{c}\text { Panjang daun } \\
(\mathrm{cm})\end{array}$ & $\begin{array}{c}\text { Berat segar } \\
\text { berangkasan }(\mathrm{gr})\end{array}$ \\
\hline $\mathrm{P}_{1}$ & $24,91 \mathrm{a}$ & $28,84 \mathrm{a}$ & $97,33 \mathrm{a}$ & $393,99 \mathrm{a}$ \\
$\mathrm{P}_{2}$ & $24,88 \mathrm{a}$ & $29,44 \mathrm{a}$ & $97,21 \mathrm{a}$ & $393,33 \mathrm{a}$ \\
$\mathrm{P}_{3}$ & $22,79 \mathrm{ab}$ & $28,44 \mathrm{ab}$ & $89,97 \mathrm{ab}$ & $384,11 \mathrm{ab}$ \\
$\mathrm{P}_{4}$ & $22,34 \mathrm{ab}$ & $27,38 \mathrm{ab}$ & $91,32 \mathrm{ab}$ & $365,66 \mathrm{ab}$ \\
$\mathrm{P}_{5}$ & $22,03 \mathrm{~b}$ & $21,40 \mathrm{~b}$ & $89,72 \mathrm{~b}$ & $360,00 \mathrm{~b}$ \\
$\mathrm{P}_{6}$ & $21,34 \mathrm{~b}$ & $21,13 \mathrm{~b}$ & $78,97 \mathrm{~b}$ & $290,11 \mathrm{~b}$ \\
\hline
\end{tabular}

Keterangan : Angka yang diikuti oleh huruf yang sama pada kolom yang sama tidak berbeda nyata pada taraf 5\% (Uji BNJ 0.05). 
Tabel 3 menunjukkan bahwa potensi jagung manis Bonanza F1 dengan jarak tanam berbeda berpengaruh sangat nyata pada semua perlakuan dalam peningkatan diameter pangkal batang, luas daun, panjang daun, berat segar berangkasan kecuali tidak berbeda nyata dengan perlakuan P2. Diameter pangkal batang, panjang daun, berat segar berangkasan terbaik dijumpai pada perlakuan P1 dan luas daun pada perlakuan P2 disajikan pada grafik dibawah ini.

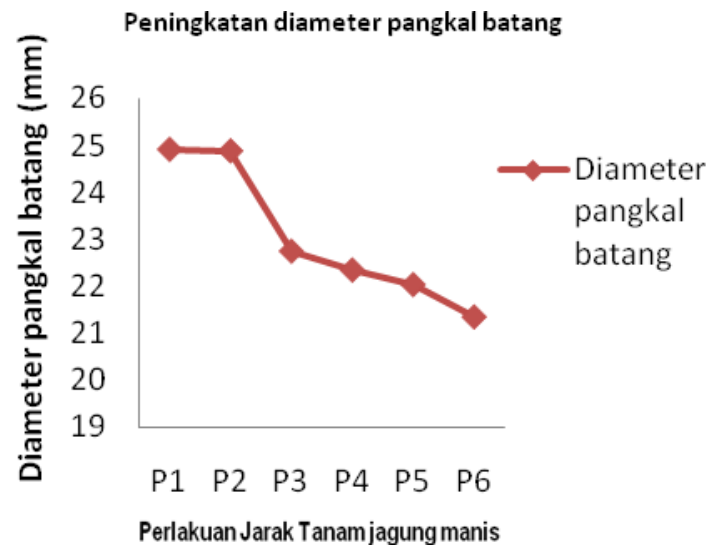

Grafik 2. Peningkatan diameter pangkal batang pada umur 45 HST dengan jarak tanam berbeda..

Grafik 2 menunjukkan bahwa (3 biji/lubang) sebesar 21,34. Hal ini di perlakuan P1 dengan jarak tanam 80 sebabkan oleh kerapatan jarak tanam $\mathrm{cm}$ x $25 \mathrm{~cm}$ (1 biji/lubang) sebesar dapat berkompetisi memperebutkan unsur 24,91 dapat memberikan diameter hara, jika ketersediaan unsur hara yang pangkal batang terbaik di banding dengan cukup dapat meningkatkan pertumbuhan perlakuan $\mathrm{P}_{2}, \mathrm{P}_{3}, \mathrm{P}_{4}, \mathrm{P}_{5}$, dan $\mathrm{P}_{6}$ terjadi pada diameter pangkal batang tanaman peningkatan dan terjadi penurunan pada jagung. perlakuan P6 jarak tanam $75 \mathrm{~cm}$ x $50 \mathrm{~cm}$

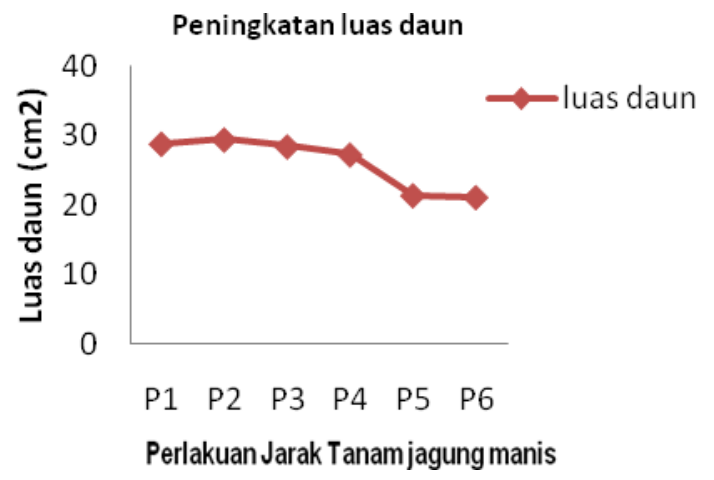

Grafik 3. Peningkatan luas daun pada umur 45 HST dengan jarak tanam berbeda.

Grafik 3 menunjukkan bahwa terjadi penurunan pada perlakuan P6 perlakuan P2 dengan jarak tanam 75 jarak tanam $75 \quad \mathrm{~cm} \quad \mathrm{x} \quad 50 \mathrm{~cm} \quad$ (3 $\mathrm{cm} \times 25 \mathrm{~cm}$ (1 biji/lubang) sebesar biji/lubang) sebesar 21,13. Hal ini di 29,44 dapat memberikan luas daun sebabkan oleh kerapatan jarak tanam terbaik di banding dengan perlakuan $\mathrm{P}_{1}, \quad$ dapat berkompetisi memperebutkan unsur $\mathrm{P}_{3}, \mathrm{P}_{4}, \mathrm{P}_{5}$,dan $\mathrm{P}_{6}$ terjadi peningkatan dan hara, jika ketersediaan unsur hara yang 
cukup dapat meningkatkan pertumbuhan lu tanaman jagung. Menurut Simanihuruk (2001) semakin besar tanaman dan rapat akan memacu tanaman untuk menyerap unsur hara, air dan cahaya untuk pertumbuhannya. Cukupnya kebutuhan terhadap unsur hara pertumbuhan akan merangsang pertambahan tinggi tanaman dan bentuk daun-daun baru. Pembentukan akan meningkatkan jumlah daun tanaman sehingga luas daun total yang dihasilkan per tanaman meningkat walau luas daun per individu kecil. Luas daun bertambah berarti meningkat pula penyerapan cahaya oleh daun.

Peningkatan panjang daun

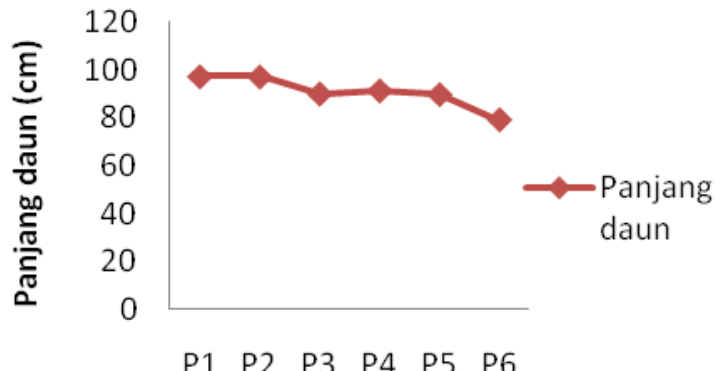

Perlakuan Jarak Tanam jagung manis

Grafik 4. Peningkatan panjang daun pada umur 45 HST dengan jarak tanam berbeda.

Grafik 4 menunjukkan bahwa perlakuan P1 dengan jarak tanam 80 $\mathrm{cm}$ x $25 \mathrm{~cm}$ (1 biji/lubang) sebesar 97,33 dapat memberikan panjang daun terbaik di banding dengan perlakuan $\mathrm{P}_{2}$, $\mathrm{P}_{3}, \mathrm{P}_{4}, \mathrm{P}_{5}$, dan $\mathrm{P}_{6}$ terjadi peningkatan dan terjadi penurunan pada perlakuan P6 jarak tanam $75 \quad \mathrm{~cm} \quad \mathrm{x} \quad 50 \mathrm{~cm} \quad(3$ biji/lubang) sebesar 78,97. Hal ini di sebabkan oleh kerapatan jarak tanam dapat berkompetisi memperebutkan unsur hara, jika ketersediaan unsur hara yang cukup dapat meningkatkan pertumbuhan pada panjang daun tanaman jagung.

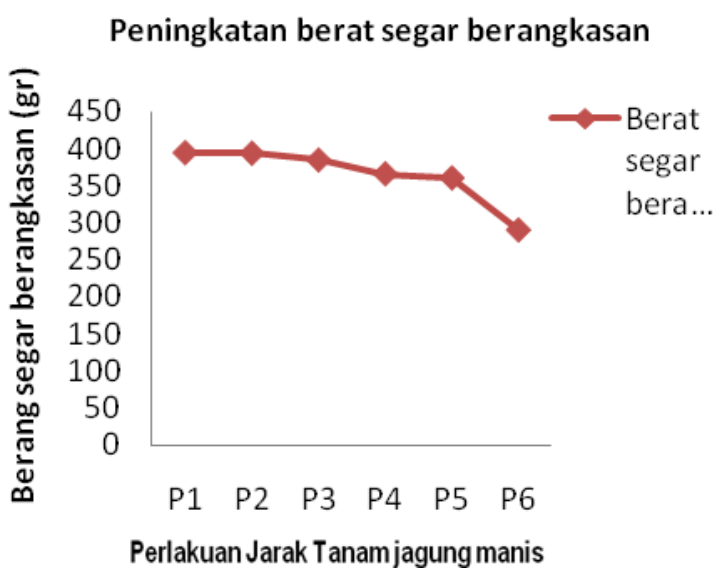

Grafik 5. Peningkatan panjang daun pada umur 45 HST dengan jarak tanam berbeda.

Grafik 5 menunjukkan bahwa perlakuan P1 dengan jarak tanam 80 $\mathrm{cm} \quad \mathrm{x} \quad 25 \mathrm{~cm}$ (1 biji/lubang) sebesar
393,99 dapat memberikan berat segar berangkasan terbaik di banding dengan perlakuan lainnya terjadi peningkatan 
dan terjadi penurunan pada perlakuan P6 jarak tanam $75 \mathrm{~cm} \quad \mathrm{x} 50 \mathrm{~cm} \quad(3$ biji/lubang) sebesar 290,11. Hal ini di sebabkan oleh kerapatan jarak tanam dapat berkompetisi memperebutkan unsur hara, jika ketersediaan unsur hara yang cukup dapat meningkatkan pertumbuhan pada berat segar berangkasan tanaman jagung.

\section{Hasil dan Komponen Hasil}

Hasil analisis sidik ragam menunjukkan bahwa potensi jagung manis Bonanza F1 dengan jarak tanam berbeda berpengaruh sangat nyata terhadap panjang tongkol, jumlah baris/tongkol, berbeda nyata pada diameter tongkol, jumlah biji/tongkol, berbeda tidak nyata pada berat tongkol berklobot, dan berat tongkol tanpa klobot. Rata-rata panjang tongkol , diameter tongkol, jumlah biji/tongkol, jumlah baris/tongkol, berat tongkol berklobot, dan berat tongkol tanpa klobot disajikan pada tabel 4 .

Tabel 4. Rata-rata hasil dan komponen hasil jagung manis Bonanza F1 dengan jarak tanam berbeda.

\begin{tabular}{|c|c|c|c|c|c|c|}
\hline & $\begin{array}{c}\text { Panjang } \\
\text { tongkol }(\mathrm{cm})\end{array}$ & $\begin{array}{c}\text { Diameter } \\
\text { tongkol }(\mathrm{cm})\end{array}$ & $\begin{array}{l}\text { Jumlah biji/ } \\
\text { tongkol (biji) }\end{array}$ & $\begin{array}{l}\text { Jumlah baris/ } \\
\text { tongkol (biji) }\end{array}$ & $\begin{array}{l}\text { Berat tongkol } \\
\text { berklobot(gr) }\end{array}$ & $\begin{array}{c}\text { Berat tongkol } \\
\text { tanpa klobot }\end{array}$ \\
\hline $\mathrm{P}_{1}$ & $26,85 \mathrm{a}$ & $53,38 \mathrm{a}$ & $511,36 \mathrm{a}$ & $15,65 \mathrm{a}$ & $340,51 \mathrm{a}$ & $285,40 \mathrm{a}$ \\
\hline $\mathrm{P}_{2}$ & $26,28 \mathrm{a}$ & $53,17 \mathrm{a}$ & $507,58 \mathrm{a}$ & $15,45 \mathrm{a}$ & $338,85 \mathrm{a}$ & $283,47 \mathrm{a}$ \\
\hline $\mathrm{P}_{3}$ & $23,87 \mathrm{ab}$ & $48,82 \mathrm{ab}$ & $426,51 \mathrm{ab}$ & $13,49 \mathrm{ab}$ & $273,65 \mathrm{ab}$ & $224,75 \mathrm{ab}$ \\
\hline $\mathrm{P}_{4}$ & $25,10 \mathrm{ab}$ & $45,07 \mathrm{ab}$ & $456,03 \mathrm{ab}$ & $15,04 \mathrm{ab}$ & $259,90 \mathrm{ab}$ & $203,40 \mathrm{ab}$ \\
\hline $\mathrm{P}_{5}$ & $21,11 \mathrm{~b}$ & $37,66 \mathrm{~b}$ & $403,56 b$ & $12,92 \mathrm{~b}$ & $242,90 b$ & $191,61 b$ \\
\hline $\mathrm{P}_{6}$ & $19,46 b$ & $34,71 \mathrm{~b}$ & $356,37 b$ & $11,36 \mathrm{~b}$ & $198,83 b$ & $141,82 b$ \\
\hline
\end{tabular}

Keterangan : Angka yang diikuti oleh huruf yang sama pada kolom yang sama tidak berbeda nyata pada taraf 5\% (Uji BNJ 0.05).

Tabel 4 menunjukkan bahwa potensi jagung manis Bonanza F1 dengan jarak tanam berbeda berpengaruh sangat nyata dengan perlakuan $\mathrm{P} 6$, berbeda tidak nyata dengan perlakuan P2 terhadap peningkatan semua hasil dan komponen hasil pada umur 45 HST. Semua hasil dan komponen hasil yang terbaik dijumpai pada perlakuan P1 disajikan pada Grafik berikut.

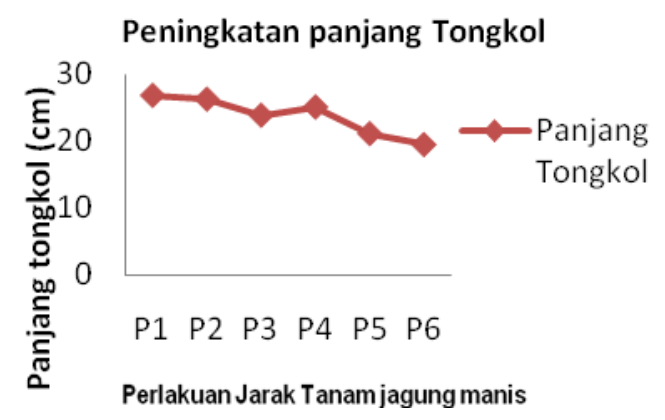

Grafik 6. Peningkatan panjang tongkol dengan jarak tanam berbeda.

Grafik 6 menunjukkan bahwa perlakuan P1 dengan jarak tanam 80 $\mathrm{cm}$ x $25 \mathrm{~cm}$ (1 biji/lubang) sebesar 26,85 dapat memberikan panjang tongkol terbaik di banding dengan perlakuan lain terjadi peningkatan dan terjadi penurunan pada perlakuan P6 jarak tanam $75 \mathrm{~cm} \mathrm{x}$ $50 \mathrm{~cm}$ (3 biji/lubang) sebesar 19,46. Hal ini di sebabkan kerapatan jarak tanam dapat berkompetisi memperebutkan unsur 
hara, jika ketersediaan unsur hara yang cukup dapat meningkatkan pertumbuhan

pada panjang tongkol tanaman jagung.

Peningkatan diameter tongkol

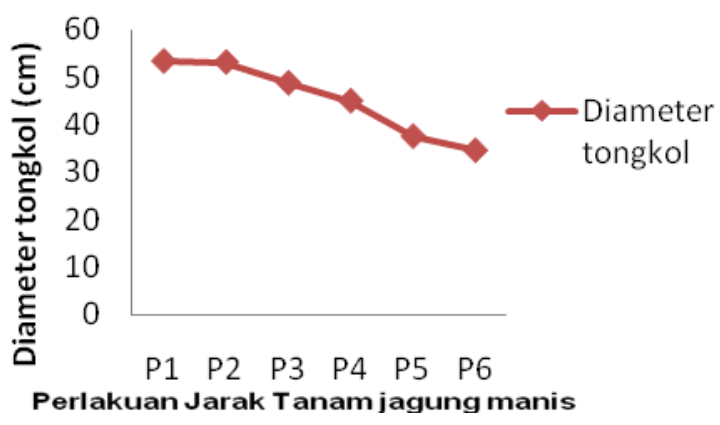

Grafik 7. Peningkatan diameter tongkol dengan jarak tanam berbeda

Grafik 7 menunjukkan bahwa perlakuan P6 jarak tanam $75 \mathrm{~cm}$ x $50 \mathrm{~cm}$ perlakuan P1 dengan jarak tanam 80 $\mathrm{cm} \times 25 \mathrm{~cm}($

1 biji/lubang) sebesar 53,38 dapat memberikan diameter tongkol terbaik di banding dengan perlakuan lain terjadi peningkatan dan terjadi penurunan pada (3 biji/lubang) sebesar 34,71. Diameter tongkol masih rendah disebabkan oleh ketersediaan kandungan nitrogen dalam proses sintesa protein masih rendah.

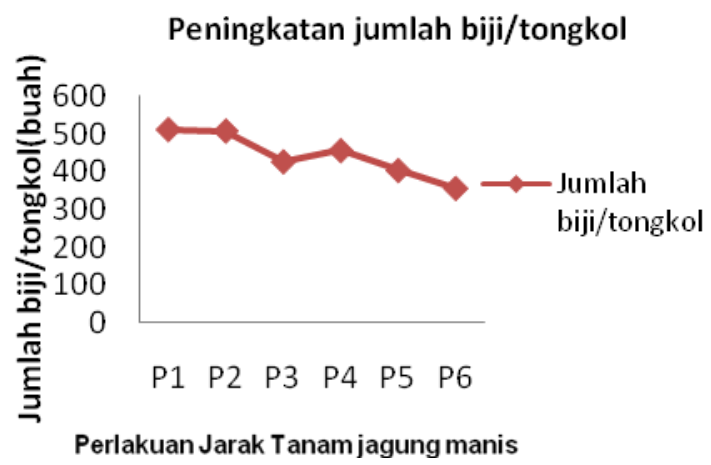

Grafik 8. Peningkatan jumlah biji/tongkol dengan jarak tanam berbeda

Grafik $\quad 8$ menunjukkan bahwa perlakuan P1 dengan jarak tanam 80 $\mathrm{cm} \quad \mathrm{x} \quad 25 \mathrm{~cm}$ (1 biji/lubang) sebesar 511,36 merupakan terbaik di banding dengan perlakuan lainnya terjadi peningkatan dan terjadi penurunan pada perlakuan P6 jarak tanam $75 \mathrm{~cm}$ x $50 \mathrm{~cm}$ (3 biji/lubang) sebesar 356,37. Hal ini di sebabkan jarak tanam salah satu faktor yang dapat mempengaruhi hasil tanaman. Peningkatan hasil jagung dapat diupayakan melalui pengaturan kerapatan tanam hingga mencapai populasi optimal. (Erawati, dkk.2016). Peningkatan tingkat kerapatan tanaman per satuan luas sampai suatu batas tertentu dapat meningkatkan hasil biji. Sebaliknya pengurangan kerapatan tanaman jagung perhektar dapat mengakibatkan perubahan iklim mikro yang mempengaruhi pertumbuhan dan hasil jagung. 


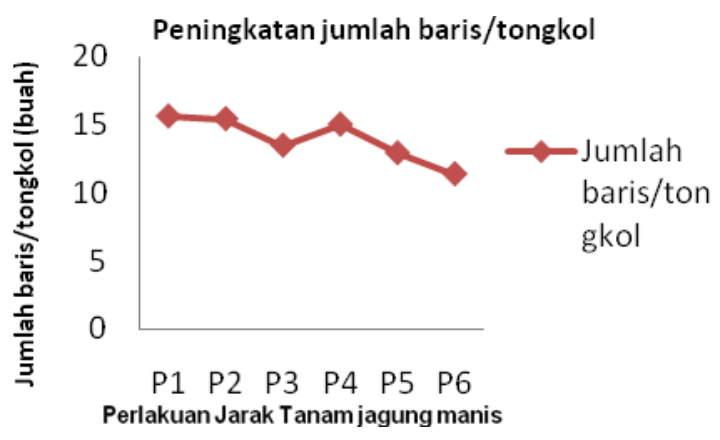

Grafik 9. Peningkatan jumlah baris/ tongkol dengan jarak tanam berbeda.

Grafik 9 menunjukkan bahwa perlakuan P1 dengan jarak tanam 80 $\mathrm{cm}$ x $25 \mathrm{~cm}$ (1 biji/lubang) sebesar 15,65 merupakan terbaik di banding dengan perlakuan lainnya terjadi peningkatan dan terjadi penurunan pada perlakuan P6 jarak tanam $75 \mathrm{~cm}$ x $50 \mathrm{~cm}$ (3 biji/lubang) sebesar 11,36. Hal ini di sebabkan jarak tanam salah satu faktor yang dapat mempengaruhi hasil tanaman. Peningkatan tingkat kerapatan tanaman per satuan luas sampai suatu batastertentu dapat meningkatkan hasil biji. Sebaliknya pengurangan kerapatan tanaman jagung perhektar dapat mengakibatkan perubahan iklim mikro yang mempengaruhi pertumbuhan dan hasil jagung. (Kartika.2018).

Peningkatan berat tongkol berklobot

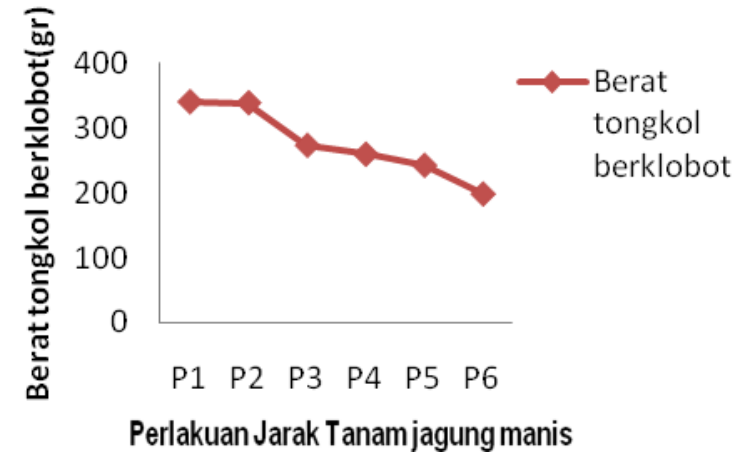

Grafik 10. Peningkatan berat tongkol berklobot dengan jarak tanam berbeda.

Grafik 10 menunjukkan bahwa perlakuan P1 dengan jarak tanam 80 $\mathrm{cm} \quad \mathrm{x} \quad 25 \mathrm{~cm}$ (1 biji/lubang) sebesar 340,51 merupakan terbaik di banding dengan perlakuan lainnya terjadi peningkatan dan terjadi penurunan pada perlakuan P6 jarak tanam $75 \mathrm{~cm}$ x $50 \mathrm{~cm}$ (3 biji/lubang) sebesar 198,83. Hal ini di sebabkan jarak tanam salah satu faktor yang dapat mempengaruhi hasil tanaman. Peningkatan hasil jagung dapat diupayakan melalui pengaturan kerapatan tanam hingga mencapai populasi optimal. (Erawati, dkk.2016).Kepadatan populasi tanaman yang tinggi akan mempengaruhi petumbuhantanaman dan pada akhirnya penampilan tanaman secara individu akan menurun karena persaingan dalam intersepsi radiasi sinar matahari, absorbsair dan unsur hara serta pengambilan $\mathrm{CO} 2$ danO2 (Indrayanti, 2010). 


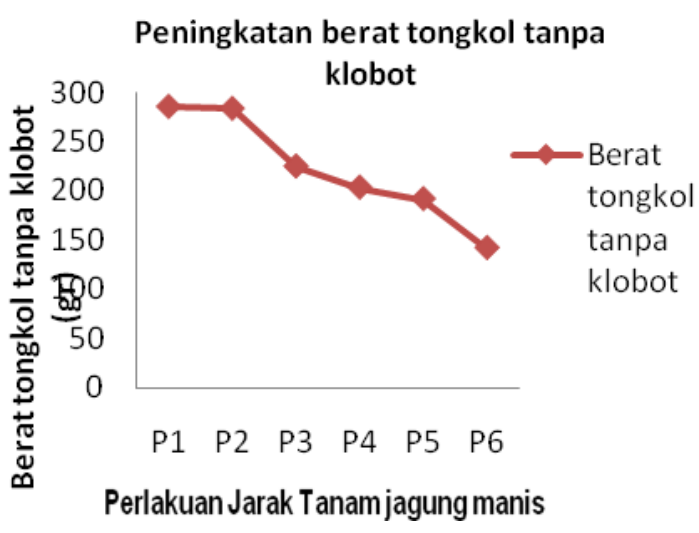

Grafik 11. Peningkatan berat tongkol tanpa klobot dengan jarak tanam berbeda.

Grafik 11 menunjukkan bahwa perlakuan P1 dengan jarak tanam 80 $\mathrm{cm} \quad \mathrm{x} \quad 25 \mathrm{~cm}$ (1 biji/lubang) sebesar 285,40 merupakan terbaik di banding dengan perlakuan lainnya terjadi peningkatan dan terjadi penurunan pada perlakuan P6 jarak tanam $75 \mathrm{~cm}$ x $50 \mathrm{~cm}$ (3 biji/lubang) sebesar 141,82.

\section{KESIMPULAN}

1. Varietas jagung Bonanza F1 berpengaruh sangat nyata pada tinggi tanaman, diameter pangkal batang, panjang tongkol dan jumlah baris per tongkol, berbeda nyata pada luas daun, panjang daun, diameter tongkol, jumlah biji per tongkol, dan tidak berbeda nyata pada berat segar berangkasan, berat tongkol berklobot, berat tongkol tanpa klobot.

2. Potensi jagung manis (Zea mays. Saccaratha Shurt) Hibrida pada jarak $\begin{array}{lllllllll}\text { tanam } & \text { P1 } & 80 & \mathrm{~cm} & \mathrm{x} & 25 & \mathrm{~cm} & \text { (1 }\end{array}$ biji/lubang) memberikan pengaruh terbaik dan memiliki potensi meningkatkan pertumbuhan, hasil dan komponen hasil tanaman jagung manis Bonanza F1.

\section{DAFTAR PUSTAKA}

Arwani A, Harwati T, Hardiatmi S. Pengaruh Jumlah Benih Per Lubang Terhadap Pertumbuhan Dan Hasil Jagung Manis (Zea
Mays Saccharata Sturt).

INNOFARM : Jurnal Inovasi

Pertanian Vol. 12, No. 2, Oktober 201.

Indrayanti, L.A. 2010. Pengaruh Jarak Tanam Dan Jumlah Benih Terhadap Pertumbuhan Vegetatif Jagung Muda. Jurnal Media Sains, Vol. 2 No. 2, Oktober 2010. Fakultas Pertanian Universitas PGRI Palangka Raya.

Direktorat Jenderal Hortikultura. 2012. Volume dan nilai impor-ekspor benih sayuran tahun 2011-2012. Tersedia Online.: http://hortikultura.deptan.go.id.

Erawati, R.T.B, Hipi A. 2016. Pengaruh Jarak Tanam terhadap Pertumbuhan dan Hasil Beberapa Varietas Jagung Hibrida di Kawasan Pengembangan Jagung Kabupaten. Sumbawa. Prosiding Seminar Nasional Inovasi Teknologi Pertanian. Banjarbaru, 20 Juli 2016.

Harjadi, S.S., 2002. Pengantar Agronomi . Jakarta : Gramedia.

Invendi. 2016. Pertumbuhan Dan Hasil Varietas Jagung Manis (Zea Mays Saccharata Sturt.) Dalam 
Tumpangsari Kacang Tanah (Arachis Hipogeae L.). Jurnal Agrotropika Hayati Vol. 3. No. 3 Agustus 2016.

Iriany RN, Sujiprihati S, Syukur M, Koswara J, Yunus M. 2011. Evaluasi daya gabung dan heterosis lima galur jagung manis (Zea mays var. saccharata) hasil persilangan dialel. J Agron Indonesia. 39(2).

Kartika,T. (2018). Pengaruh Jarak Tanam Terhadap Pertumbuhan Dan Produksi Jagung (Zea Mays L) Non Hibrida Di Lahan Balai Agro Teknologi Terpadu (Atp). Jurnal SAINMATIKA. Vol. 15 No. 2. 2018.

Novriani 2010. Alternatif Pengelolaan Unsur Hara P (Fosfor) Pada Budidaya Jagung. Jurnal Agronobis, Vol.2, No.3, Maret 2010.

Probowati RA, Guritno B, Sumarni T. 2014. Pengaruh tanaman penutup tanah dan jarak tanam pada gulma dan hasil tanaman jagung Zea mays L. Jurnal Produksi Tanaman. Vol. 2. No. 8. Desember 2014.

Simanihuruk WB. 2001. Analisis Pertumbuhan Tanaman Jagung Manis (Zea mays saccharata) Pergeseran Komposisi Gulma pada Beberapa Jarak Tanam.Jurnal Ilmu Pertanian Indonesia. Vol. 3. $\mathrm{N}$ o. 1. 2001. 